\title{
Implementasi Algoritma Apriori untuk Rekomendasi Produk pada Toko Online
}

\author{
Implementation of Apriori Algorithms for Product Recommendations \\ at Online Stores
}

\author{
Esha Alma'arif*1, Ema Utami², Ferry Wahyu Wibowo ${ }^{3}$ \\ 1,2,3 Magister Teknik Informatika, Universitas AMIKOM Yogyakarta \\ E-mail: *1esha.a@students.amikom.ac.id, 20ma.u@amikom.ac.id, ${ }^{3}$ ferry.w@amikom.ac.id
}

\begin{abstract}
Abstrak
Perkembangan pasar digital yang semakin pesat menimbulkan persaingan dalam menarik pelanggan menjadi semakin ketat. Setiap pemilik toko online berusaha mencari strategi supaya tokonya mampu bertahan. Strategi yang bisa diterapkan yaitu dengan memberikan rekomendasi produk yang sesuai dengan keinginan konsumen. Kemampuan pemilik toko dalam melihat keinginan dan kebutuhan konsumen akan berdampak pada peningkatan penjualan. Dengan kemampuan tersebut pemilik toko dapat menata produknya dan membuat promosi menggunakan kombinasi produk tertentu. Algoritma apriori adalah teknik yang dipakai pada penelitian ini. Dalam algoritma tersebut dilakukan proses iterasi menggunakan nilai minimum support dan confidence guna menilai setiap kombinasi produk. Kemudian mengeliminasi kombinasi barang yang tidak mencapai minimum support. Berdasarkan algoritma tersebut diperoleh frekuensi barang yang paling banyak dibeli bersamaan untuk memberi manfaat pada manajemen dalam menyusun dan mengkombinasikan produk untuk mengoptimalkan pemasaran. Selanjutnya memanfaatkan nilai confidence yang memberikan gambaran tentang relasi antar produk. Implementasi algoritma apriori bisa dimanfaatkan guna menganalisa data transaksi pada periode tertentu. Sehingga hasil informasi yang dihasilkan algoritma ini bisa dimanfaatkan pada strategi pemasaran dan promosi produk yang sesuai oleh keinginan pelanggan.
\end{abstract}

Kata Kunci-Rekomendasi, Support, Confidence, dan Algoritma Apriori.

The rapid development of the digital market has led to increased competition in attracting customers. Every online shop owner tries to find strategy to make the store survive. Strategy that can be applied is to provide product recommendations that are in accordance with consumer desires. The ability of shop owners to see the desires of consumers will have an impact on increasing sales. With these capabilities shop owners can arrange their products and make promotions using certain product combinations. The technique used in this study is apriori algorithm. In the algorithm the iteration process uses a value of minimum support and confidence to assess each product combination. Then eliminate combinations that do not meet the minimum support. Based on the algorithm, we found the frequency of products that most often appear together to help management organize products to optimize marketing. The final result uses the value of confidence which gives an idea of the relationship between products. Apriori algorithm implementation can be utilized to analyze transaction data for a certain period. So the results of the information generated by this algorithm can be utilized in marketing strategies and product promotions according to customer desires.

Keywords - Recommendations, Support, Confidence, and Apriori Algorithm. 


\section{PENDAHULUAN}

Peran teknologi sangat besar di berbagai aspek kehidupan tanpa terkecuali pada sektor perdagangan. Salah satu dampak dari perkembangan teknologi adalah maraknya toko online yang mengubah pola konsumen dalam melakukan transaksi. Meskipun banyak muncul toko online baru, tapi banyak toko online yang tidak mampu bertahan lama, karena persaingan yang sangat ketat. Banyaknya kesalahan dalam pemasaran produk oleh pemilik usaha sehingga mengeluarkan banyak biaya terhadap produk yang tidak diminati konsumen. Mengetahui pola belanja konsumen adalah hal yang sangat penting dalam menghadapi masalah ini. Penggunaan data mining sangat sesuai untuk memberikan solusi dalam masalah ini. Keinginan konsumen dalam memilih produk memang sangat beragam. Sebagai contoh, saat membeli produk di toko online, konsumen akan ditawarkan berbagai produk mulai dari produk dalam bentuk paket, produk tambahan, dan produk dengan diskon. Berbagai strategi dalam memasarkan produk untuk meningkatkan penjualan dengan harapan akan membuat konsumen membeli produk tersebut. Salah satu cara dalam menawarkan produk adalah dengan memberikan rekomendasi kepada konsumen. Memberikan rekomendasi produk kepada pelanggan salah satunya adalah dengan menentukan rekomendasi produk yang sesuai. Pada penelitian ini algoritma apriori diimplementasikan pada toko online untuk menemukan aturan asosiasi antar produk. Implementasi algoritma apriori pada toko online dapat memberikan peranan penting bagi pemilik toko, untuk menentukan rekomendasi dalam menawarkan produk terkait berdasarkan pola belanja konsumen.

Kumpulan data transaksi konsumen bisa dikelola guna menemukan informasi yang mampu digunakan untuk mengambil langkah yang tepat dalam menyusun strategi pemasaran [1]. Analisa data dapat menggunakan sebuah algoritma tertentu. Algoritma apriori adalah salah satu algoritma yang dapat diimplementasikan pada penelitian tersebut [2]. Apriori merupakan bagian dari algoritma pencarian frequent item set dengan menggunakan metode aturan asosiatif (association rule) [3]. Aturan asosiatif merupakan bagian dari tahapan pada Market Basket Analysis untuk menemukan keterkaitan diantara produk atau barang dari suatu dataset yang kemudian dipaparkan pada aturan asosiatif [4]. Proses menemukan association rule pada kumpulan data, proses awal yang perlu dilakukan yaitu menemukan frequent itemset yang merupakan sekelompok produk yang biasa muncul dengan bersamaan. Association rule akan menemukan pola yang mampu menghubungkan suatu data dengan yang lain. Apabila semua pola frequent itemset sudah ditemukan, proses berikutnaya adalah menemukan aturan asosiatif yang sesuai dengan syarat yang ditentukan [5].

Apabila produk yang dipasarkan di toko online adalah semesta, maka setiap produk mempunyai parameter boolean yang menunjukkan keberadaan produk tersebut pada suatu transaksi atau satu keranjang belanja. Berdasarkan pola dari nilai parameter itu dipakai guna menumukan produk-produk yang banyak dibeli secara bersamaan. Selanjutnya pengetahuan tentang frekuensi item tersebut digunakan untuk memproses informasi untuk menemukan produk yang mungkin akan muncul dan melampaui syarat minimum support dan minimum confidence. Support sebagai persentase kombinasi sebuah item dari kumpulan data [6]. Dan confidence yaitu nilai kepastian yang menggambarkan kekuatan relasi antar item pada algoritma Apriori. Confidence dapat ditentukan apabila pola frekuensi kemunculan item sudah ditemukan [7].

Pada penggunaan teknik data mining berbagai macam algoritma dapat digunakan untuk mendapatkan informasi. Algoritma tersebut antara lain algoritma FP-Growth, algoritma hashbased, dan algoritma apriori [8]. Khusus untuk penelitian ini, peneliti mengimplementasikan algoritma apriori. Pada penelitian ini memaparkan suatu sistem rekomendasi display produk toko online dengan metode algoritma apriori berdasarkan nilai confidence kombinasi jenis-jenis produk yang dibeli pada periode waktu tertentu dengan tujuan sebagai rekomendasi kepada pemilik toko online atau manajer dalam pengambilan keputusan display produk yang dijual.

Listriani memaparkan proses analisa asosiasi dengan algoritma apriori yang mampu menemukan pola kombinasi item sebagai knowledge dan informasi yang sangat bermanfaat dari data transaksi penjualan. Penelitian tersebut menerapkan algoritma apriori untuk menemukan kombinasi item dari data transaksi, serta menemukan pola asosiasi berdasarkan kombinasi item 
yang ditemukan. Pola asosiasi yang ditemukan pada nilai minimum support 5\% dengan nilai minimum confidence 15\% membentuk 7 aturan asosiasi. Kemudian pola belanja yang dihasilkan dianalisa menggunakan aplikasi menjadi suatu rekomendasi dalam menentukan strategi pemasaran oleh pengelola Toko Gramedia [9]. Pada penelitian lain, Aprizal mengimplementasikan algoritma apriori pada teknik data mining dapat menyusun posisi penempatan produk pada rak Alfamidi. Metode analisa pola pembelian bisa diterapkan dengan memperhatikan kecenderungan konsumen belanja produk dengan kombinasi 2 itemset. Pengujian terhadap aplikasi yang telah dibuat menggunakan metode Black Box [10]. Lestari melakukan penelitian terhadap transaksi yang terjadi yang dilakukan pada penelitian Lestari, memanfaatkan algoritma apriori untuk mengembangkan strategi pemasaran dan meningkatkan penjualan. Penelitian tersebut menghasilkan sebuah sistem informasi yang dapat mengimplementasikan algoritma apriori ke dalam sebuah program berorientasi objek yang mempermudah dalam pengaksesan data penjualan, dimana data mining algoritma apriori dapat mengekstrak informasi bahan bangunan yang sering dibeli konsumen dari database yang terintegrasi dengan sistem informasi penjualan, adalah: apabila membeli kuas, maka membeli tiner, dengan nilai support 50 $\%$ dan nilai confidence $100 \%$ [11].

\section{METODE PENELITIAN}

Metode yang digunakan pada penelitian ini adalah metodologi Prototype. Dahulu prototype menggambarkan rancangan fisik menggunakan kertas. Dimana analis menggambarkan posisi atau struktur dari input, output, prosedur, dan basis data. Hal tersebut adalah proses yang membutuhkan waktu dan memungkinkan kesalahan terjadi. Pada umumnya apa yang dihasilkan dari rancangan kertas tidak akurat dan kurang lengkap. Sekarang sebagian besar analis lebih sering menggunakan prototyping. Metodologi Prototyping merupakan suatu proses iterative dengan menjalin komunikasi dan kinerja yang dekat antara developer dengan user perangkat lunak.

Pressman mengemukakan bahwa seorang pengguna sering menganggap perangkat lunak sebagai tujuan secara umum, tanpa memberikan idenfifikasi terhadap kebutuhan input, proses, dan output secara detail. Masalah yang lain, developer tidak mendapatkan kepastian tentang algoritma yang efisien, kemampuan untuk menyesuaikan sistem operasi, maupun tahapan yang semestinya dilakukan pada interaksi manusia dan mesin. Sehingga untuk situasi ini salah satu metode paling sesuai untuk diterapkan adalah metode prototype. Alur Metodologi Prototype bisa dipaparkan dengan Gambar 1.

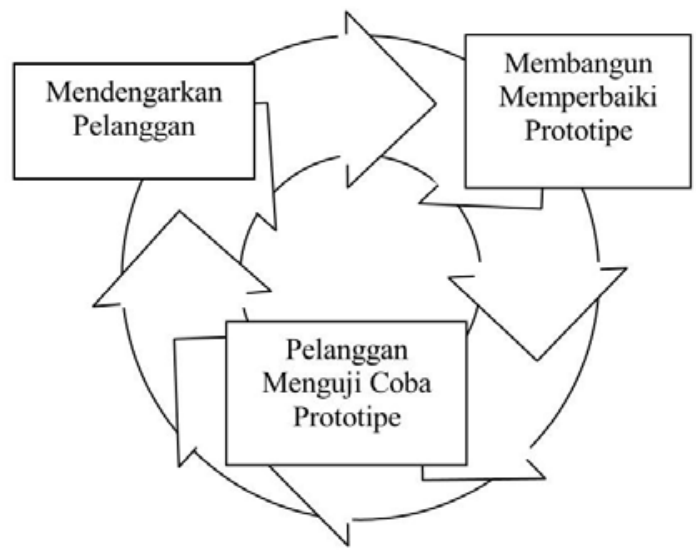

Gambar 1. Alur Penelitian menggunakan metode prototype. 
Metodologi ini sangat sesuai digunakan untuk membangun suatu sistem yang akan dikembangkan kembali. Metodologi ini diawali dengan mengumpulkan kebutuhan pengguna. Pada kasus ini user dari sistem yang dibangun adalah client. Selanjutnya membuat sebuah rancangan dengan cepat yang kemudian akan dievaluasi sebelum dikembangkan. Prototype bukanlah sistem yang sudah selesai, tetapi merupakan rancangan yang harus dievaluasi dan dikembangkan lagi. Setiap pergantian bisa terjadi saat pembuatan prototype sesuai permintaan client dan memberikan manfaat pada developer dengan lebih memahami keinginan client. Metodologi ini melewati tiga tahap, diantaranya adalah pengumpulan kebutuhan, perancangan, dan evaluasi. Tahapan-tahapan tersebut dapat dipaparkan sebagai berikut [12]:

a. Pengumpulan kebutuhan

Developer dan client berdiskusi dan menentukan tujuan pembuatan sistem. Kemudian mencari kebutuhan dalam perancangan sistem dan gambaran sistem sesuai dengan yang diinginkan oleh client.

b. Perancangan

Perancangan dibuat dengan cepat dan dapat mewakili berbagai aspek sistem yang diperoleh berdasarkan pengumpulan kebutuhan pada tahap sebelumnya. Rancangan tersebut kemudian sebagai acuan desain prototype.

c. Evaluasi Prototype

Setelah prototype selesai dikembangkan. Kemudian client mengevaluasi prototype tersebut dan digunakan untuk memberikan rincian dan memberikan keterangan lebih detail terhadap kebutuhan perangkat lunak.

Ketiga proses tersebut di atas akan terus berulang sampai segala kebutuhan terpenuhi. Prototype diciptakan guna memahami kebutuhan client. Prototype dapat digunakan kembali untuk membuat sistem lebih cepat, tapi tidak setiap prototype bisa digunakan. Meskipun prototype memberi kemudahan komunikasi antara developer dengan client, sehingga client mendapat gambaran awal dari sistem yang dibangun.

\section{HASIL DAN PEMBAHASAN}

\subsection{Analisa Desain Sistem}

Proses analisa dan desain sistem dimulai dari pengumpulan data-data terkait pada transaksi pembelian pelanggan di toko online. Dari data yang diperoleh kemudian dibuat aturan asosiatif (Association rule) dalam data historis pembelian dari pengunjung Toko online untuk mencari hubungan asosiatif dari sebuah kombinasi item produk yang telah dibeli oleh konsumen. Metode perhitungan menggunakan mekanisme pembentukan support dan confidence berdasarkan relasi antar item. Suatu aturan asosiasi dinilai menarik apabila nilai support lebih besar dari minimum support, serta nilai confidence yang lebih besar dari minimum confidence. Penerapan teknik apriori dilakukan apabila ditemukan beberapa relasi antar item yang akan dianalisa. Pengujian dari pengolahan data mining nantinya dari hasil output rekomendasi produk yang sesuai untuk pelanggan akan dilakukan secara bertahap dengan melihat data histori pembelian konsumen selanjutnya pada periode tertentu. Tahapan proses analisa dan desain sistem digambarkan pada gambar 2 [13].

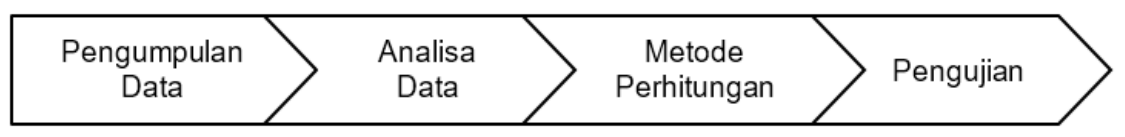

Gambar 2. Tahapan Proses Analisa dan Desain Sistem 
Citec Journal, Vol. 7, No. 1, Januari 2020

ISSN: 2354-5771

\subsection{Pengumpulan Data}

Tahap pertama analisis desain sistem adalah melakukan pengumpulan data histori pembelian pelanggan yaitu menentukan rentan waktu yang diambil dari history transaksi untuk digunakan sebagai data sampel dalam penelitian ini. Kemudian menyusun kumpulan data transaksi tersebut kedalam sebuah tabel seperti yang dipaparkan pada Tabel 1.

Tabel 1. Pola Transaksi Pembelian Pelanggan

\begin{tabular}{|c|l|}
\hline Transaksi & Item Transaksi \\
\hline 1 & Kerudung, Tas, Gamis, Khimar, Rok \\
\hline 2 & Celana, Kemeja, Jaket, Khimar, Gamis \\
\hline 3 & Khimar, Kerudung, Kemeja, Dompet, Gamis \\
\hline 4 & Hand Sock, Khimar, Kemeja, Bros, Kerudung \\
\hline 5 & Dompet, Kemeja, Tas, Kaos Kaki, Hand Sock \\
\hline 6 & Sepatu, Celana, Bros, Kemeja \\
\hline 7 & Kemeja, Celana, Khimar, Jam Tangan, Rok \\
\hline 8 & Kaos Kaki, Khimar, Gamis, Jaket, Kerudung \\
\hline 9 & Gamis, Dompet, Bros, Rok, Kerudung \\
\hline 10 & Jaket, Sepatu, Gamis, Khimar, Kerudung \\
\hline 11 & Gamis, Tas, Kemeja, Masker, Rok, Khimar \\
\hline 12 & Masker, Jaket, Celana, Jam Tangan, Gamis, Rok \\
\hline 13 & Rok, Khimar, Gamis, Masker, Kerudung, Dompet \\
\hline 14 & Rok, Hand Sock, Kerudung, Khimar, Jaket \\
\hline 15 & Kerudung, Dompet, Sepatu, Bros \\
\hline 16 & Kaos Kaki, Kerudung, Dompet, Kemeja, Gamis \\
\hline 17 & Jam Tangan, Kerudung, Celana, Khimar, Gamis \\
\hline 18 & Rok, Kemeja, Jam Tangan, Hand Sock, Kerudung \\
\hline 19 & Celana, Kerudung, Jaket, Gamis, Rok, Kemeja \\
\hline 20 & Dompet, Hand Sock, Gamis, Bros, Khimar \\
\hline
\end{tabular}

\subsection{Matriks Data Transaksi}

Berdasarkan data transaksi yang telah dikumpulkan kemudian dibentuk matriks data transaksi. Pada tahap ini data transaksi pembelian pelanggan akan disesuaikan dalam format matriks untuk mendapatkan pola item yang terbentuk, dan digunakan untuk mengetahui berapa kali item produk dibeli oleh pelanggan pada setiap transaksinya, berikut data yang dipaparkan pada Tabel 2.

Tabel 2. Matriks Transaksi Pembelian Pelanggan

\begin{tabular}{|l|c|c|c|c|c|c|c|c|c|c|c|c|c|c|c|c|c|c|r|r|r|}
\hline \multirow{2}{*}{\multicolumn{1}{|c|}{ Item }} & \multicolumn{10}{|c|}{ Transaksi } & \multirow{10}{*}{ Jml } \\
\cline { 2 - 19 } & $\mathbf{1}$ & $\mathbf{2}$ & $\mathbf{3}$ & $\mathbf{4}$ & $\mathbf{5}$ & $\mathbf{6}$ & $\mathbf{7}$ & $\mathbf{8}$ & $\mathbf{9}$ & $\mathbf{1 0}$ & $\mathbf{1 1}$ & $\mathbf{1 2}$ & $\mathbf{1 3}$ & $\mathbf{1 4}$ & $\mathbf{1 5}$ & $\mathbf{1 6}$ & $\mathbf{1 7}$ & $\mathbf{1 8}$ & $\mathbf{1 9}$ & $\mathbf{2 0}$ & \\
\hline Kerudung & 1 & 0 & 1 & 1 & 0 & 0 & 0 & 1 & 1 & 1 & 0 & 0 & 1 & 1 & 1 & 1 & 1 & 1 & 1 & 1 & $\mathbf{1 4}$ \\
\hline Tas & 1 & 0 & 0 & 0 & 1 & 0 & 0 & 0 & 0 & 0 & 1 & 0 & 0 & 0 & 0 & 0 & 0 & 0 & 0 & 0 & 3 \\
\hline Gamis & 1 & 1 & 1 & 0 & 0 & 0 & 0 & 1 & 1 & 1 & 1 & 1 & 1 & 0 & 0 & 1 & 1 & 0 & 1 & 1 & $\mathbf{1 3}$ \\
\hline Celana & 0 & 1 & 0 & 0 & 0 & 1 & 1 & 0 & 0 & 0 & 0 & 1 & 0 & 0 & 0 & 0 & 1 & 0 & 1 & 0 & $\mathbf{6}$ \\
\hline Kemeja & 0 & 1 & 1 & 1 & 1 & 1 & 1 & 0 & 0 & 0 & 1 & 0 & 0 & 0 & 0 & 1 & 0 & 1 & 1 & 0 & $\mathbf{1 0}$ \\
\hline Jaket & 0 & 1 & 0 & 0 & 0 & 0 & 0 & 1 & 0 & 1 & 0 & 1 & 0 & 1 & 0 & 0 & 0 & 0 & 1 & 0 & $\mathbf{6}$ \\
\hline Khimar & 1 & 1 & 1 & 1 & 0 & 0 & 1 & 1 & 1 & 1 & 1 & 1 & 1 & 1 & 0 & 0 & 1 & 0 & 0 & 1 & $\mathbf{1 4}$ \\
\hline Hand Sock & 0 & 0 & 0 & 1 & 1 & 0 & 0 & 0 & 0 & 0 & 0 & 0 & 0 & 1 & 0 & 0 & 0 & 1 & 0 & 1 & 5 \\
\hline Bros & 0 & 0 & 0 & 1 & 0 & 1 & 0 & 0 & 1 & 0 & 0 & 0 & 0 & 0 & 1 & 0 & 0 & 0 & 0 & 1 & 5 \\
\hline Dompet & 0 & 0 & 1 & 0 & 1 & 0 & 0 & 0 & 1 & 0 & 0 & 0 & 1 & 0 & 1 & 1 & 0 & 0 & 0 & 1 & 7 \\
\hline Sepatu & 0 & 0 & 0 & 0 & 0 & 1 & 0 & 0 & 0 & 1 & 0 & 0 & 0 & 0 & 1 & 0 & 0 & 0 & 0 & 0 & 3 \\
\hline
\end{tabular}




\begin{tabular}{|c|c|c|c|c|c|c|c|c|c|c|c|c|c|c|c|c|c|c|c|c|c|}
\hline \multirow{2}{*}{ Item } & \multicolumn{20}{|c|}{ Transaksi } & \multirow{2}{*}{ Jml } \\
\hline & 1 & 2 & 3 & 4 & 5 & 6 & 7 & 8 & 9 & 10 & 11 & 12 & 13 & 14 & 15 & 16 & 17 & 18 & 19 & 20 & \\
\hline Kaos Kaki & 0 & 0 & 0 & 0 & 1 & 0 & 0 & 1 & 0 & 0 & 0 & 0 & 0 & 0 & 0 & 1 & 0 & 0 & 0 & 0 & 3 \\
\hline Masker & 0 & 0 & 0 & 0 & 0 & 0 & 0 & 0 & 0 & 0 & 1 & 1 & 1 & 0 & 0 & 0 & 0 & 0 & 0 & 0 & 3 \\
\hline Rok & 1 & 0 & 0 & 0 & 0 & 0 & 1 & 0 & 1 & 0 & 1 & 1 & 1 & 1 & 0 & 0 & 0 & 1 & 1 & 0 & 9 \\
\hline Jam Tangan & 0 & 0 & 0 & 0 & 0 & 0 & 1 & 0 & 0 & 0 & 0 & 1 & 0 & 0 & 0 & 0 & 1 & 1 & 0 & 0 & 4 \\
\hline
\end{tabular}

\subsection{Analisis Metode Apriori}

Pada tahap ini bertujuan untuk mencari kombinasi dari item-item menggunakan pola frekuensi berdasarkan history transaksi pada toko online.

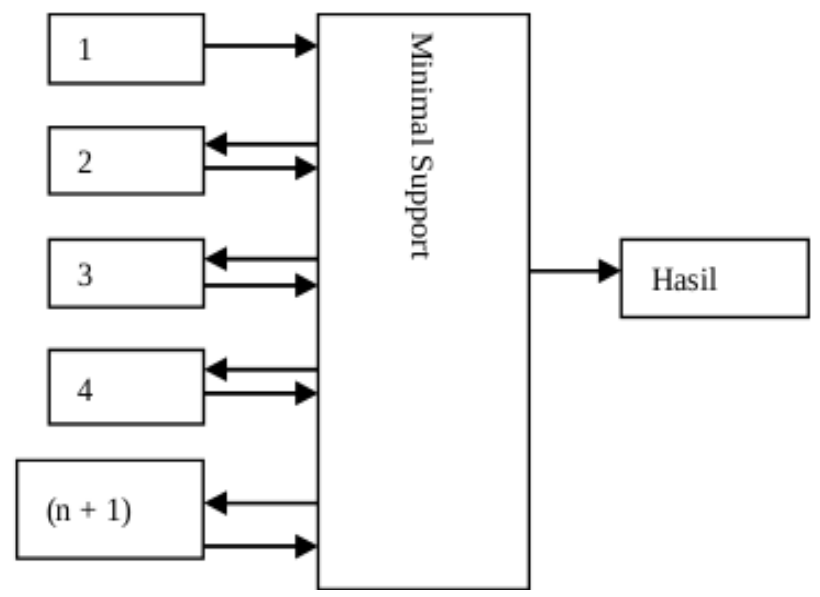

Gambar 3. Bagan Alur Apriori

Pada Gambar 3 menjelaskan algoritma apriori dimana proses senantiasa berlangsung apabila keadaan data dapat memungkinkan untuk pembentukan itemset selanjutnya. Apabila tidak dimungkinkan maka proses dapat langsung menunjukan hasil. Matriks transaksi pembelian pelanggan akan diambil jumlah transaksi masing-masing item produk per transaksi dan jumlah data transaksi kemudian digunakan untuk menentukan kombinasi itemset.

\subsubsection{Analisa Kombinasi 1 Itemset}

Kombinasi 1 itemset ini merupakan pengolahan dari data yang telah disertakan di tabel 2. Proses penentuan $K_{1}$ atau disebut sebagai kombinasi 1 itemset pada nilai minimum support $=$ $40 \%$, menggunakan rumus pada persamaan (1) [14].

$$
\text { Support }(\text { Item })=\frac{\sum \text { transaksi mengandung Item }}{\sum \text { transaksi }}
$$

Proses perhitingan pada persamaan (1) diperoleh data yang dipaparkan pada Tabel 3, untuk nilai support masing-masing item produk.

Tabel 3. Nilai support dari setiap item produk

\begin{tabular}{|l|r|r|}
\hline \multicolumn{1}{|c|}{ Item } & Jumlah & Support \\
\hline Kerudung & 14 & $70 \%$ \\
\hline Tas & 3 & $15 \%$ \\
\hline Gamis & 13 & $65 \%$ \\
\hline Celana & 6 & $30 \%$ \\
\hline Kemeja & 10 & $50 \%$ \\
\hline
\end{tabular}


Citec Journal, Vol. 7, No. 1, Januari 2020

\begin{tabular}{|l|r|r|}
\hline Jaket & 6 & $30 \%$ \\
\hline Khimar & 14 & $70 \%$ \\
\hline Hand Sock & 5 & $25 \%$ \\
\hline Bros & 5 & $25 \%$ \\
\hline Dompet & 7 & $35 \%$ \\
\hline Sepatu & 3 & $15 \%$ \\
\hline Kaos Kaki & 3 & $15 \%$ \\
\hline Masker & 3 & $15 \%$ \\
\hline Rok & 9 & $45 \%$ \\
\hline Jam Tangan & 4 & $20 \%$ \\
\hline
\end{tabular}

Penentuan itemset di Tabel 3 pada minimum support 40\% mampu ditemukan produk yang melampaui syarat minimum support adalah item produk Kerudung, Gamis, Kemeja, Khimar, Rok. Kemudian berdasarkan hasil pembentukan kombinasi 1 itemset dapat dibentuk kombinasi 2 itemset yang dipaparkan di Tabel 4.

\subsubsection{Analisa Kombinasi 2 Itemset}

Kombinasi 2 Itemset ini adalah pengolahan menggunakan data yang dipaparkan pada tabel 3 diambil item dan nilai support masing-masing item produk, proses penentuan $K_{2}$ atau disebut dengan kombinasi 2 itemset pada jumlah minimum support $=40 \%$, menggunakan rumus pada persamaan (2) [14].

$$
\text { Support }(P \cap Q)=\frac{\sum \text { transaksi mengandung } P \& Q}{\sum \text { transaksi }}
$$

Tabel 4. Nilai support dari kombinasi 2 itemset produk

\begin{tabular}{|l|r|r|}
\hline \multicolumn{1}{|c|}{ Item } & Jumlah & Support \\
\hline Kerudung, Gamis & 10 & $\mathbf{5 0 \%}$ \\
\hline Kerudung, Kemeja & 5 & $25 \%$ \\
\hline Kerudung, Khimar & 10 & $\mathbf{5 0 \%}$ \\
\hline Kerudung, Rok & 6 & $30 \%$ \\
\hline Gamis, Kemeja & 5 & $25 \%$ \\
\hline Gamis, Khimar & 11 & $\mathbf{5 5 \%}$ \\
\hline Gamis, Rok & 6 & $30 \%$ \\
\hline Kemeja, Khimar & 6 & $30 \%$ \\
\hline Kemeja, Rok & 4 & $20 \%$ \\
\hline Khimar, Rok & 7 & $35 \%$ \\
\hline
\end{tabular}

Kombinasi 2 itemset pada minimum support 40 \% bisa ditemukan kombinasi 3 itemset yang melampaui syarat minimum support antara lain Kerudung dengan Gamis dan Kerudung dengan Khimar yang memiliki nilai support sebesar 50\%. Kemudian Gamis dengan Khimar yang memiliki nilai support $55 \%$. Berdasarkan pada nilai kombinasi 2 itemset, kemudian diproses pengelompokan 3 itemset yang dipaparkan pada Tabel 5.

\subsubsection{Analisa Kombinasi 3 Itemset}

Kombinasi 3 Itemset ini merupakan pengelompokan produk dari data yang dipaparkan di tabel 4. Dari tabel tersebut dipilih item yang memenuhi nilai support dari masing-masing produk. Kemudian dilanjutkan dengan tahap pembentukan $K_{3}$ biasa disebut dengan kombinasi 3 itemset pada jumlah minimum support $=40 \%$, menggunakan rumus pada persamaan (3) [15]. 


$$
\operatorname{Support}(P, Q, R)=\frac{\sum \text { transaksi mengandung } P, Q \text { dan } R}{\sum \text { transaksi }}
$$

Tabel 5. Nilai support dari kombinasi 3 itemset produk

\begin{tabular}{|c|r|r|}
\hline Item & Jumlah & Support \\
\hline Kerudung, Gamis, Khimar & 8 & $40 \%$ \\
\hline
\end{tabular}

\subsection{Pembentukan Aturan Asosiasi}

Tahap selanjutnya adalah membentuk aturan asosiasi pada saat semua pola frekuensi tinggi sudah didapatkan. Pada proses ini ditemukan aturan asosiasi yang melewati syarat minimum untuk confidence berdasarkan perhitungan confidence aturan asosiatif $\mathrm{P} \rightarrow \mathrm{Q}$, persamaan ditunjukkan pada persamaan (4) [15]. Dengan menentukan minimum Confidence = 70\%, maka nilai Confidence pada aturan $\mathrm{P} \rightarrow \mathrm{Q}$ didapatkan:

$$
\text { Confidence }=(Q \mid P)=\frac{\sum \text { transaksi mengandung } P \& Q}{\sum \text { transaksi mengandung } P}
$$

Dari persamaan tersebut kemudian ditemukan aturan asosiasi antar produk yang memilik nilai confidence paling tinggi. Pembentukan aturan asosiasi tersebut dapat dijelaskan lebih detil pada Tabel 6.

\begin{tabular}{|l|r|r|}
\hline \multicolumn{1}{|c|}{ Aturan } & Jumlah & Confidence \\
\hline Jika membeli Kerudung maka membeli Gamis & $10 / 14$ & $71.43 \%$ \\
\hline Jika membeli Khimar maka membeli Gamis & $11 / 14$ & $78.57 \%$ \\
\hline
\end{tabular}

Tabel 6. Nilai support dari kombinasi 3 itemset produk.

Pada Tabel 6, barang yang banyak dibeli oleh pelanggan adalah Kerudung, Gamis, Khimar. Setelah mengetahui barang yang banyak dibeli pelanggan, maka pemilik usaha bisa menyusun strategi dalam menentukan pengadaan produk untuk mengelola ketersedian barang yang diinginkan oleh pelanggan. Serta dapat menata posisi produk dan paket promosi menggunakan kombinasi itemset produk yang dihasilkan.

\subsection{Implementasi Sistem}

Kemudian algoritma apriori diimplementasikan pada toko online, untuk menentukan association rule. Dengan association rule tersebut management toko dapat memberikan rekomendasi produk pada konsumen. Penelitian ini menggunakan data sample transaksi pada bulan Juni 2019 untuk memberikan rekomendasi produk pada bulan Juli 2019. Berdasarkan transaksi-transaksi tersebut maka association rule diambil sebagai dasar untuk menentukan rekomendasi produk. Pada Gambar 4 menampilkan kategori produk pada transaksi tersebut. 
Citec Journal, Vol. 7, No. 1, Januari 2020

ISSN: 2354-5771

\begin{tabular}{|c|c|c|}
\hline \multicolumn{3}{|c|}{ Jumlah data: 20} \\
\hline No & Tanggal & Kategori Produk \\
\hline 1 & 2019-06-01 & kerudung,tas,gamis,khimar,rok \\
\hline 2 & 2019-06-02 & celana,kemeja,jaket,khimar,gamis \\
\hline 3 & 2019-06-03 & khimar,kerudung,kemeja,dompet,gamis \\
\hline 4 & 2019-06-04 & handsock,khimar,kemeja,bros,kerudung \\
\hline 5 & 2019-06-05 & dompet,kemeja,tas,kaoskaki,handsock \\
\hline 6 & 2019-06-06 & sepatu,celana,bros,kemeja \\
\hline 7 & 2019-06-07 & kemeja,celana,khimar,jamtangan,rok \\
\hline 8 & 2019-06-08 & kaoskaki,khimar,gamis,jaket,kerudung \\
\hline 9 & 2019-06-09 & gamis,dompet,bros,rok,kerudung,khimar \\
\hline 10 & 2019-06-10 & jaket,sepatu,gamis,khimar,kerudung \\
\hline 11 & 2019-06-11 & gamis,tas,kemeja,masker,rok,khimar \\
\hline 12 & 2019-06-12 & masker,jaket,celana,jamtangan,gamis,rok,khimar \\
\hline 13 & $2019-06-13$ & rok,khimar,gamis,masker,kerudung,dompet \\
\hline 14 & $2019-06-14$ & rok,handsock,kerudung,khimar,jaket \\
\hline 15 & 2019-06-15 & kerudung,dompet,sepatu,bros \\
\hline 16 & 2019-06-16 & kaoskaki,kerudung,dompet,kemeja,gamis \\
\hline 17 & $2019-06-17$ & jamtangan,kerudung,celana,khimar,gamis \\
\hline 18 & 2019-06-18 & rok,kemeja,jamtangan,handsock,kerudung \\
\hline 19 & 2019-06-19 & celana,kerudung,jaket,gamis,rok,kemeja \\
\hline 20 & 2019-06-20 & dompet,handsock,gamis,bros,khimar,kerudung \\
\hline
\end{tabular}

Gambar 4. Sistem Menampilkan Contoh Data Transaksi.

\section{Hasil Analisa}

\section{Export Excel}

1. Jika konsumen membeli kerudung, gamis, maka konsumen juga akan membeli khimar

2. Jika konsumen membeli gamis, khimar, maka konsumen juga akan membeli kerudung

3. Jika konsumen membeli khimar, kerudung, maka konsumen juga akan membeli gamis

4. Jika konsumen membeli kerudung, maka konsumen juga akan membeli gamis

5. Jika konsumen membeli gamis, maka konsumen juga akan membeli kerudung

6. Jika konsumen membeli kerudung, maka konsumen juga akan membeli khimar

7. Jika konsumen membeli khimar, maka konsumen juga akan membeli kerudung

8. Jika konsumen membeli gamis, maka konsumen juga akan membeli khimar

9. Jika konsumen membeli khimar, maka konsumen juga akan membeli gamis

Gambar 5. Sistem Menampilkan Hasil Analisa Transaksi. 
Gambar 5 menunjukan hasil analisa transaksi menggunakan algoritma apriori. Dari data jenis-jenis produk tersebut dengan menerapkan algoritma apriori dengan menerapkan nilai minimum support $40 \%$, dan nilai minimum confidence $70 \%$ sehingga menghasilkan nilai confidence dari berbagai kombinasi itemset. Berdasarkan nilai kombinasi item set dengan nilai confidence tertinggi sistem mampu memberikan rekomendasi produk seperti yang ditunjukan pada Gambar 6.

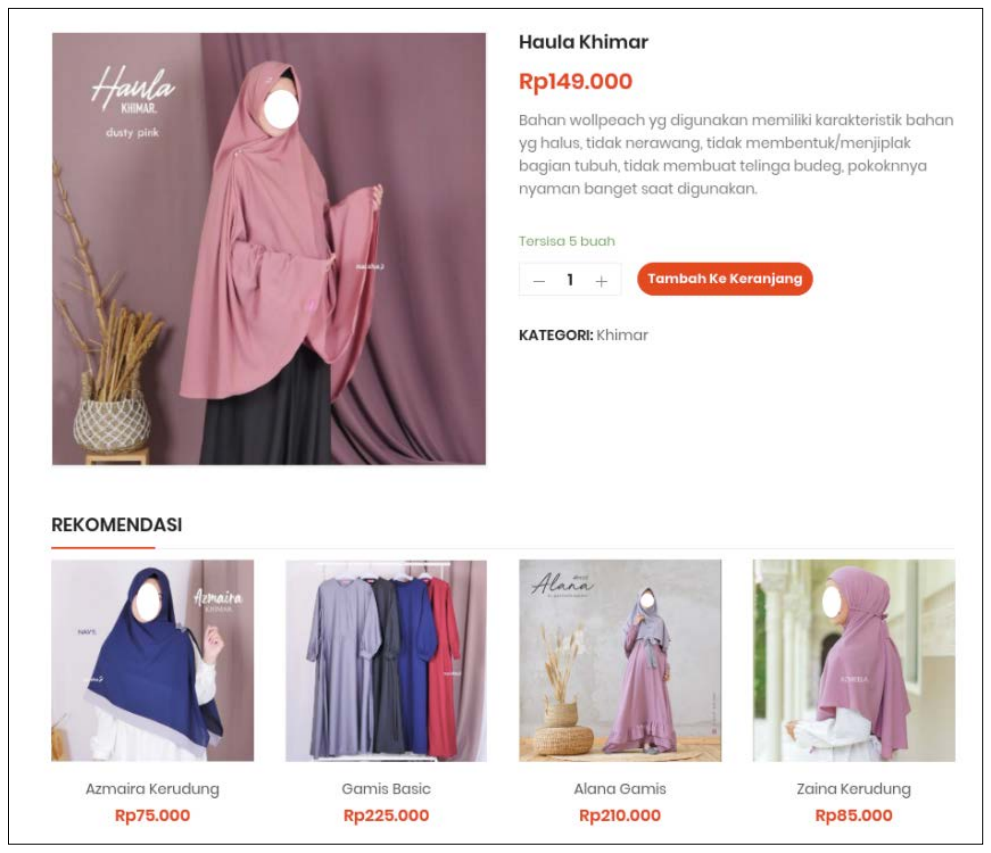

Gambar 6. Hasil Rekomendasi Produk

\subsection{Pengujian}

Perhitungan menggunakan algoritma apriori dan dari perhitungan menggunakan sistem yang dibangun dipaparkan pada tabel 6. Dengan menentukan nilai minimum support $40 \%$ dan nilai minimum confidence $70 \%$ dapat menghasilkan rekomendasi produk toko online yang dibeli oleh pelanggan dipaparkan pada Tabel 7.

Tabel 7. Perbandingan hasil perhitungan.

\begin{tabular}{|l|l|}
\hline \multicolumn{1}{|c|}{ Teknik Perhitungan } & \multicolumn{1}{c|}{ Hasil } \\
\hline Perhitungan dengan menggunakan metode & Jika membeli Khimar maka membeli \\
Apriori & Gamis dengan nilai confidence 78.57\% \\
\hline $\begin{array}{l}\text { Perhitungan dengan menggunakan sistem yang } \\
\text { dibangun }\end{array}$ & Jika membeli Khimar maka membeli \\
& Gamis dengan nilai confidence 78.57\% \\
\hline
\end{tabular}

Pengujian pada algoritma apriori dan pada sistem yang dikembangkan memiliki nilai yang sama, serta memenuhi nilai minimum support dan minimum confidence yang ditentukan sebelumnya. Berdasarkan perhitungan tersebut maka sistem ini dapat menemukan rekomendasi produk dari kecenderungan produk toko online yang dibeli oleh konsumen yang terdiri dari kombinasi itemset produk. Hasil dari implementasi dan pengujian dapat memberikan peranan penting bagi management dalam mengelola display toko online berdasarkan prioritas produk yang ditawarkan, serta menyusun etalase yang terdiri dari berbagai itemset produk secara berdekatan untuk memberikan kemudahan pada konsumen dalam mencari produk yang diinginkan. 


\section{KESIMPULAN}

Kesimpulan yand dapa diambil berdasarkan pembahasan dan pemaparan penelitian yang sudah dilakukan sebagai berikut:

1. Implementasi Algoritma Apriori pada bisa digunakan untuk menemukan kombinasi item pada data history transaksi. Selanjutnya menemukan pola asosiasi berdasarkan kombinasikombinasi item tersebut.

2. Penerapan algoritma apriori dapat memberikan rekomendasi produk pada toko online berdasarkan nilai confidence kombinasi jenis-jenis produk yang dibeli oleh konsumen.

\section{SARAN}

Pengembangan untuk penelitian berikutnya bisa menggunakan data berukuran besar supanya memperoleh rekomendasi itemset produk yang akurat. Selain itu juga dapat dibandingkan lagi dengan algoritma lain supaya mendapatkan hasil rekomendasi yang lebih akurat. Penelitian ini perlu melakukan pengujian lebih lanjut secara bertahap untuk mendapatkan hasil akurasi rekomendasi yang lebih sesuai dengan minat konsumen.

\section{DAFTAR PUSTAKA}

[1] Kusrini., Luthfi, E. T., 2009. Algoritma Data Mining, Andi Publisher, Yogyakarta.

[2] Turban, E., 2005, Decision Support Systems and Intelligent Systems Edisi Bahasa Indonesia. Andi Publisher, Yogyakarta.

[3] Hermawati, F. A., 2013, Data Mining. Andi, Yogyakarta.

[4] Kusrini., 2007, Konsep dan Aplikasi Sistem Pendukung Keputusan, Andi Publisher, Yogyakarta.

[5] O’brien, J. A., Marakas, G. M., 2014, Sistem Informasi Manajemen, Salemba Empat, Jakarta

[6] Han, J., Kamber, M., Pei, J., 2006, Data Mining Concept and Techniques, Elsevier Inc, Amsterdam

[7] Bhandari, A., Guptaa, A., Dasa, D., 2014, Improvised apriori algorithm using frequent pattern tree for realtime applications in data mining, International Conference on Information and Communication Technologies (ICICT 2014), Bandung, 28-30 Mei

[8] Du, J., Zhang, X., Zhang, H., Chen, L., 2016, Research and Improvement of Apriori Algorithm, Information Science and Technology (ICIST) - 2016 Sixth International Conference, Dalian, 6 - 8 Mei

[9] Listriani, D., Setyaningrum, A. H., Eka, F., 2016, Penerapan Metode Asosiasi Menggunakan Algortima Apriori Pada Aplikasi Analisa Pola Belanja Konsumen (Studi Kasus Toko Buku Gramedia Bintaro), Jurnal Teknik Informatika, No. 2, Vol. 9.

[10] Aprizal., Hasriani., Ningsih, W., 2016, Implementasi Data Mining Untuk Menentukan Posisi Barang Pada Rak Menggunakan Metode Apriori Pada PT. Midi Utama Indonesia, Techno.COM, No. 4, Vol. 15, Hal.335-342.

[11] Lestari, N., 2017, Penerapan Data Mining Algoritma Apriori Dalam Sistem Informasi Penjualan, Jurnal Edik Informatika, No. 2, Vol. 3, Hal. 103-114. 
[12] Pressman, 2010, Software Engineering: A Practitioner's Approach, McGraw-Hill, New York

[13] Fatoni, C. S., Noviandha, F. D., Case Based Reasoning Diagnosis Penyakit Difteri dengan Algoritma K-Nearest Neighbor, Citec Journal, Vol. 4, No. 3, Hal. 220-232.

[14] Yanto, R., Khoiriah, R., Implementasi Data Mining dengan Metode Algoritma Apriori dalam Menentukan Pola Pembelian Jaket, Citec Journal, Vol. 2, No. 2, Hal. 102-113.

[15] Ummi, K., Analisa Data Mining Dalam Penjualan Sparepart Mobil Dengan Menggunakan Metode Algoritma Apriori (Studi Kasus: Di Pt. Idk 1 Medan), CSRID, Vol. 8, No. 3, Hal. 145-208. 